\title{
INHERITANCE OF SOME MUTANT TRAITS IN SUNFLOWER
}

\author{
Soroka, A. ${ }^{*}{ }^{\text {, Lyakh, } \text { V. }^{2}}$ \\ ${ }^{1}$ Institute of Oilseed Crops, UAAS, Vesenniaya str. 1, Solnechny, \\ Zaporozhye, 70417, Ukraine \\ ${ }^{2}$ Zaporozhye National University, Zhukouskogo str. 66, \\ Zaporozhye, 69600, Ukraine
}

Received: May 05, 2011

Accepted: June 30, 2011

\begin{abstract}
SUMMARY
The subject of our study was the inheritance of some mutant traits in cultivated sunflower which were found after treating immature embryos of ZL-95 line with a chemical mutagen ethylmethanesulphonate. It was shown that the traits of dichotomous leaf venation and tobacco-like plant are recessive and inherited as monogenic traits when cross-bred with the source line. The given traits are inherited independently when cross-breeding mutant lines with each other and the genes that define them are probably localized in different chromosomes.
\end{abstract}

Key words: sunflower, mutation, inheritance, morphological trait, $F_{2}$ population, segregation

\section{INTRODUCTION}

Cultivated sunflower is one of the basic oil crops in the world, occupying the area of more than 20 million hectares during the recent years. Considering the fact that many breeding centers are involved in the development of new evaluations of this new crop data about the inheritance of morphological, physiological or other traits in sunflower there has been an increased demand for them. At present time the development of modern high-yielding sunflower varieties and hybrids, resistant to biotic and abiotic environmental factors, is substantially restrained because of its narrow genetic basis (Gavrilova, Anisimova, 2003; Kirichenko, 2005). As a consequence, there is a genetic uniformity of raised varieties and hybrids. Therefore, development of any techniques promoting extending of genetic variability in this crop is an highly necessary and extremely important task. Similar problems can be successfully solved with a variety of methods, such as using the interspecific and intergeneric hybridization, induced mutagenesis, some biotechnological techniques, etc. (Jambhulkar, Joshua, 1999; Sukno et al., 1999; Faure et al., 2002).

* Corresponding author: Phone: 38061 2891204; e-mail: genetika@znu.edu.ua 
We have carried out extensive work on induced mutagenesis in cultivated sunflower for several years. This included mutagenic exposure/treatment of immature seeds (Lyakh et al., 2005) and mutagen treatment of immature embryos of different ages (Soroka, Lyakh, 2009). In the course of those studies there was a series of mutants with now traits. The genetics of those traits, however, has not been practically studied, despite the importance of such knowledge for breeders. With regard to this, the aim of the present paper was to study the inheritance of certain morphological mutant traits identified during previous stages of our work.

\section{MATERIALS AND METHODS}

The inheritance in $\mathrm{F}_{1}$ and $\mathrm{F}_{2}$ of two morphological mutant traits - dichotomous venation of leaves, and tobacco-like plant, when cross-bred with the source line ZL95 and between themselves, was the subject of our study.

The mutant lines of sunflower with dichotomous venation of leaves and tobacco-like leaves were cultivated after being treated with a chemical mutagen ethylmethanesulphonate of immature embryos of ZL-95 line, originating from the collection of the Institute of Oilseed Crops NAAS (Soroka, Lyakh, 2009).

The analysis of the inheritance of mutant traits was carried out following the well-known general techniques for genetic analysis of qualitative traits (Serebrovsky, 1970). Segregation analysis and hypothesis testing was performed using the $\chi^{2}$ criterion (Lakin, 1990).

\section{RESULTS AND DISCUSSION}

\section{Inheritance of mutant traits in $F_{1}$ and $F_{2}$ when cross-breeding mutants with the source line}

The mutation named by us as "leaf dichotomous venation" was a complex mutation and included not only type of leaf venation, but the leaf shape and petiolestem angle as well (Figure 1). This mutation was found in the $\mathrm{M}_{3}$ generation after 910 - old embryo treatment of ZL-95 line. The $F_{1}$ hybrids after cross-breeding this mutation with the source line were not different from the source line, taking the type of leaf venation into account. Leaves of all $F_{1}$ plants possessed a reticulated venation. In the generation $\mathrm{F}_{2}$ most of the plants carried the same trait as the $\mathrm{F}_{1}$ hybrids. Approximately a quarter of plants had a dichotomous type of leaf venation. A segregation analysis performed showed that the trait of leaf dichotomous venation was a recessive one and inherited as a monogenic trait when cross-bred with the source line (Table 1).

The mutation named "tobacco-like plant" is a complex mutation as well, and includes not only leaf shape, but length of internodes, number and size of ray florets as well (Figure 2). This mutation is already visible at the seedling stage and 
demonstrates itself with wide and oval cotyledons. It was also found in the $\mathrm{M}_{3}$ generation after treatment of line ZL-95 young embryos with ethylmethanesulphonate.

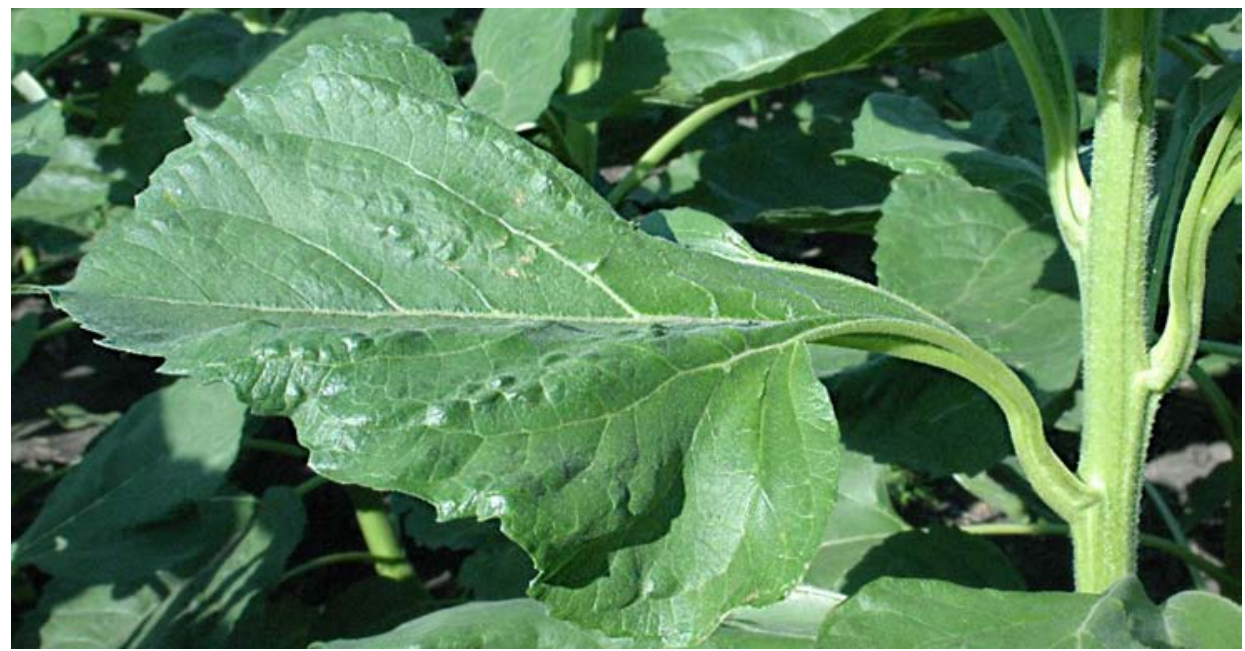

Figure 1: A mutant with leaf dichotomous venation

Table 1: Inheritance of traits «dichotomous venation of leaves» and «tobacco-like plant» when crossing mutant lines to the source line

\begin{tabular}{|c|c|c|c|c|c|c|}
\hline \multirow[b]{2}{*}{ Crossing } & \multirow{2}{*}{$\begin{array}{l}\mathrm{F}_{1} \text { pheno- } \\
\text { type }\end{array}$} & \multirow{2}{*}{$\begin{array}{l}\text { Number } \\
\text { of } F_{2} \\
\text { plants }\end{array}$} & \multicolumn{2}{|c|}{ Phenotypes of $\mathrm{F}_{2}$} & \multirow{2}{*}{$\begin{array}{l}\text { Segregation } \\
\text { model }\end{array}$} & \multirow[b]{2}{*}{$\chi^{2}$} \\
\hline & & & $\begin{array}{c}\text { Normal } \\
\text { trait }\end{array}$ & $\begin{array}{l}\text { Mutant } \\
\text { trait }\end{array}$ & & \\
\hline $\begin{array}{l}\text { Source line }(\text { normal) } \times \\
\text { Dichotomous venation plant }\end{array}$ & $\begin{array}{l}\text { Normal } \\
\text { plants }\end{array}$ & 95 & 73 & 22 & $3: 1$ & 0,22 \\
\hline $\begin{array}{l}\text { Source line }(\text { normal) } \times \\
\text { tobacco-like plant }\end{array}$ & $\begin{array}{l}\text { Normal } \\
\text { plants }\end{array}$ & 68 & 56 & 12 & $3: 1$ & 1,96 \\
\hline
\end{tabular}

When cross-breeding the original line ZL-95 with a mutant which possessed the trait of "tobacco-like plant" all the $\mathrm{F}_{1}$ hybrids had an elongated leaf, typical of the source line. It can be seen from the results of segregation analysis (Table 1) that about one quarter of $\mathrm{F}_{2}$ plants had the leaves of oval shape, which indicates the recessive type of inheritance of the given mutation. Inheritance of that trait proceeded according to $3: 1$ segregation model $\left(\chi^{2}=1,96\right)$.

\section{Inheritance of mutant traits in $F_{1}$ and $F_{2}$ when cross-breeding mutant lines among themselves}

Table 2 presents the data about the inheritance of mutant traits "tobacco-like plant" and "dichotomous venation" in cross-breeding of mutants with each other. The progenies after selfing three hybrid plants were analyzed individually. As it can be seen from the table $F_{1}$, the plants had normal phenotypes in all cases, i.e. normal (elongated) leaf shape and reticulated venation of the leaves. In $\mathrm{F}_{2}$ segregation 


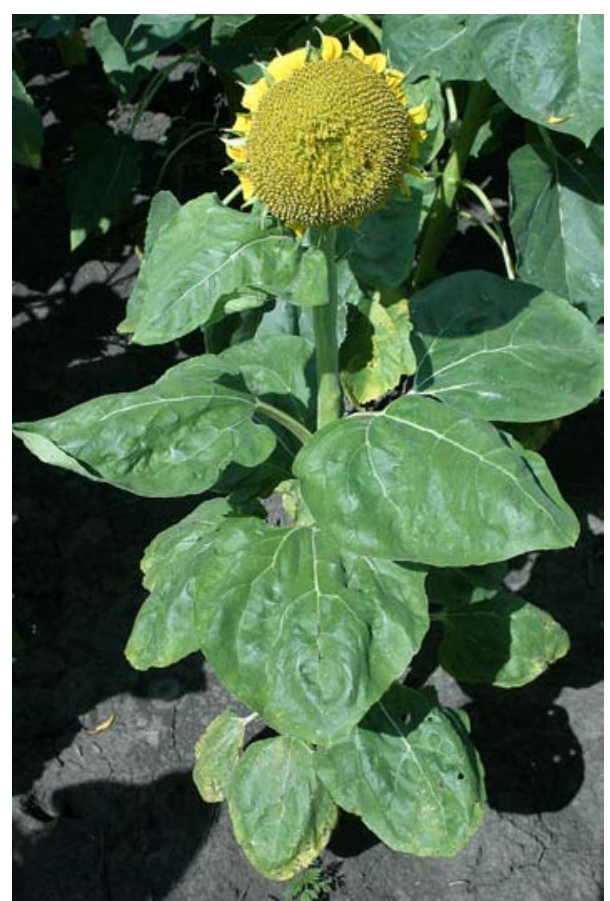

Figure 2: A tobacco-like plant with shortened internodes and oval leaves close to 9:3:3:1 was observed. Thus, in populations No.1, 102 plants had normal phenotype, 32 plants possessed normal leaf shape and dichotomous leaf venation, 32 plants were tobaccolike and had reticulated leaf venation, and 6 plants were both tobacco-like and with dichotomous venation of leaves. To determine whether the segregation we observed differ from the theoretically expected 9:3:3:1, $\chi^{2}$ was calculated. Based on this we drew a conclusion that the given segregation did not differ from the Mendelian one and confirmed the dihybrid segregation with independent inheritance of genes. Thus, the given mutant traits are recessive, inherited independently, and genes that define them are probably localized in different chromosomes.

Similar segregations were observed within two other $\mathrm{F}_{2}$ populations after cross-breeding tobacco-like mutants with mutants with dichotomous leaf venation (Table 2).

Table 2: Inheritance of traits «dichotomous venation of leaves» and «tobacco-like plant» when crossing mutant lines between themselves

\begin{tabular}{|c|c|c|c|c|c|c|c|c|c|}
\hline \multirow{3}{*}{$\begin{array}{l}\text { Popula- } \\
\text { tion } \\
\text { number }\end{array}$} & \multicolumn{4}{|c|}{$\mathrm{F}_{2}$ observed } & \multicolumn{4}{|c|}{$\mathrm{F}_{2}$ expected } & \multirow{3}{*}{$\chi^{2}$} \\
\hline & \multicolumn{2}{|c|}{$\begin{array}{l}\text { Reticulated } \\
\text { venation }\end{array}$} & \multicolumn{2}{|c|}{$\begin{array}{c}\text { Dichotomous } \\
\text { venation }\end{array}$} & \multicolumn{2}{|c|}{$\begin{array}{l}\text { Reticulated } \\
\text { venation }\end{array}$} & \multicolumn{2}{|c|}{$\begin{array}{c}\text { Dichotomous } \\
\text { venation }\end{array}$} & \\
\hline & $\begin{array}{c}\text { normal } \\
\text { leaf }\end{array}$ & $\begin{array}{l}\text { tobacco- } \\
\text { shaped leaf }\end{array}$ & $\begin{array}{c}\text { normal } \\
\text { leaf }\end{array}$ & $\begin{array}{c}\text { tobacco- } \\
\text { shaped leaf }\end{array}$ & $\begin{array}{c}\text { normal } \\
\text { leaf }\end{array}$ & $\begin{array}{c}\text { tobacco- } \\
\text { shaped leaf }\end{array}$ & $\begin{array}{c}\text { normal } \\
\text { leaf }\end{array}$ & $\begin{array}{l}\text { tobacco- } \\
\text { shaped leaf }\end{array}$ & \\
\hline 1 & 105 & 32 & 32 & 6 & 98 & 33 & 33 & 11 & 2,7 \\
\hline 2 & 54 & 20 & 24 & 5 & 58 & 19 & 19 & 7 & 1,74 \\
\hline 3 & 49 & 18 & 11 & 3 & 46 & 15 & 15 & 5 & 1,86 \\
\hline
\end{tabular}

\section{CONCLUSIONS}

After the study of inheritance of some mutant traits in sunflower, it was found that the traits of "leaf dichotomous venation" and "tobacco-like plant" are recessive and inherited independently. Such inheritance pattern makes it possible to involve them in breeding programs for the given crop easily. 


\section{REFERENCES}

Faure, N., Serieys, H., Cazaux, E., Kaan, F., Berville, A., 2002. Partial hybridization in wide crosses between cultivated sunflower and the perennial Helianthus species H.mollis and H.gyalis. Annals of Botany 89: 31-39.

Gavrilova, V.A., Anisimova, I.N., 2003. Genetics of cultivated plants. Sunflower. St.Pt.: VIR: 209. (In Russian).

Jambhulkar, S.G., Joshua, D.C., 1999. Induction of plant injury, chimera, chlorophyll and morphological mutations in sunflower using gamma rays. Helia 31: 63-74.

Kirichenko, V.V., 2005. Breeding and seed production of sunflower (Helianthus annuus L.): Monograph. Kharkov: 387. (In Russian).

Lakin, G.F., 1990. Biometrics. Moscow: Vysshaya shkola: 351. (In Russian).

Lyakh, V.A., Polyakova, I.A., Soroka, A.I., 2009. Induced mutagenesis of oilseed crops. Zaporozhye: ZNU: 266. (In Russian)

Lyakh, V., Soroka, A., Vasin, V., 2005. Influence of mature and immature sunflower seed treatment with ethylmethanesulphonate on mutation spectrum and frequency. Helia 43 : 87-98.

Serebrovskiy, A., 1970. Genetic analysis. Moscow: Nauka: 342. (In Russian)

Soroka, A., Lyakh, V., 2009. Genetic variability in sunflower after mutagen treatment of immature embryos of different age. Helia 51: 33-46.

Sukno, S., Ruso, J., Jan, C.C., Melero-Vara, J.M., Fernandez-Martinez, J.M., 1999. Interspecific hybridization between sunflower and wild perennial Helianthus species via embryo rescue. Euphytica 106: 69-78.

\section{HERENCIA DE ALGUNOS RASGOS MUTANTES EN GIRASOL}

\section{RESUMEN}

Se estudió la herencia de algunos rasgos mutantes en el girasol cultivado que se encontraron despues del tratamiento de los embriones inmaduros de la linea ZL-95 de acuerdo con un mutágeno químico etilometanosulfonato. Se ha demostrado que los rasgos de venación dicotómica de la hoja y la planta del tipo tabaco son recesivos y heredados como rasgos monogénicos en cruzas con la línea ZL-95. Los rasgos se heredan de forma independiente, y los genes que definen estos rasgos son probablemente localizados en cromosomas diferentes. 
